\title{
Framing contractual performance incentives: effects on supplier behaviour
}

\author{
Kostas Selviaridis* \\ Department of Management Science \\ Lancaster University Management School \\ Wendy van der Valk \\ Department of Management \\ Tilburg School of Economics and Management \\ Tilburg University
}

To appear in the International Journal of Operations \& Production Management

Accepted: 22 July 2018

*Corresponding author: Department of Management Science, Lancaster University Management School, Lancaster, LA1 4YX. Tel.:+44(0)1524594602. Email: k.selviaridis@lancaster.ac.uk 


\title{
Framing contractual performance incentives: effects on supplier behaviour
}

\begin{abstract}
Purpose - This paper investigates the effects that the framing of contractual performance incentives has on supplier behavioural and relational responses and on the buyer-supplier relationship.

Design/ methodology/ approach - We conducted three in-depth case studies of contractual relationships, which exhibit differences in terms of how performance incentives are framed i.e. using promotion, prevention, and 'hybrid' frames respectively. The study involved 38 semistructured interviews and content analysis of contract agreements.

Findings - First, while promotion-framed incentives lead to positive supplier responses and improved relationships, prevention-framed incentives result in negative responses and deteriorating relations. Second, hybrid-framed incentives can lead to productive supplier responses when positive ex-ante expectations are met, although the creation of such positive expectations in the first place depends on the proportionality of bonus and penalty elements. Third, promotion- and hybrid-framed incentives do not by default lead to positive effects, as these are contingent on factors pertaining to contractual clarity. Fourth, the overarching purpose of the contract moderates the effects of contract framing on supplier responses.
\end{abstract}

Research limitations/ implications - The study contributes to contracting research by showing how the framing of performance incentives influences supplier behavioural and relational responses. It also extends existing literature on contract framing by examining the effects of hybrid-framed incentives, and stressing that contract framing should be considered in joint with the clarity and overall purpose of the contract to elicit desired supplier behaviours.

Practical implications - Managers of buying firms may differentiate their approach to contract framing depending on the type of supplier relationship in focus. Furthermore, effective design of promotion- and hybrid-framed incentives requires attention to: a) realistic performance targets (on the short, medium and long term); b) salient bonuses related to these targets; c) incentive structures that appropriately balance rewards and risks; and: d) mechanisms that explicate and consider uncontrollable factors in the calculation of bonus /malus payments.

Originality/ value - The paper extends the literature stressing the psychological impact of contracts on buyer-supplier relationships by highlighting that contractual clarity and the overarching purpose of the contract moderate the effects of contract framing on supplier behavioural and relational responses.

Article classification: Research paper

Keywords: framing; performance incentives; contracting; buyer-supplier relationships. 


\section{Introduction}

Formal contracts play a key role in the governance of buyer-supplier relationships, often complementing relational mechanisms (Roehrich and Lewis, 2014; Wacker et al., 2016). A key characteristic of contracts is the structure of incentives offered to suppliers, which refers to fixed or variable payment tied to efforts or results (Hypko et al., 2010). Performance incentives involve financially compensating a supplier for agreed-upon outcomes (also referred to as performance-based pay or pay-for-performance (Caldwell and Howard, 2014; Selviaridis and Spring, 2018)), and are typical in performance-based contracting (PBC) (Sumo et al., 2016; Datta and Roy, 2011).

Generally, performance incentives are considered to elicit supplier behaviours that are productive; i.e., behaviours that have positive effects; e.g. promoting performance improvement, cost efficiency and innovation (Randall et al., 2011; Sumo et al., 2016). However, unproductive behaviours, i.e., behaviours having negative effects, resulting from perverse incentives, such as supplier opportunism, may also be at play (Koning and Heinrich, 2013). Overall, the effectiveness of contractual performance incentives, that is, the extent to which they trigger supplier responses that have positive effects, largely depends on how these are designed and executed (Selviaridis and Wynstra, 2015; Essig et al., 2016).

One important contract design issue is the way in which provisions are framed (Cao and Lumineau, 2015; Schepker et al., 2014). In the specific context of inter-firm contracting, framing refers to the way contractual provisions are articulated. For example, contractual incentives can be designed using a 'promotion' or gain frame that awards suppliers a bonus in case performance targets are met or even exceeded; or a 'prevention' or loss frame, which imposes a penalty in case performance targets are not met (Weber and Mayer, 2011). Promotion frames are suggested to instigate flexibility, creative behaviour and buyer-supplier collaboration to achieve the specified exchange goals (Weber and Mayer, 2011), while 
prevention frames are suggested to induce vigilant behaviour and arm's length relations. The work underlying these notions is however mostly conceptual in nature; empirical evidence on the impact of contract framing on buyer-supplier relationships remains very limited (Weber, 2017). In particular, the extant (performance-based) contracting literature has underplayed the role of framing and the supplier responses it triggers.

This paper therefore empirically examines the effects of framing contractual performance incentives on supplier behaviour; more specifically, the supplier's responses regarding the exchange and the ongoing buyer-supplier relationship. The study investigates the (un)productive supplier responses that emerge under contracts that exhibit differences in terms of how performance incentives are framed. The fieldwork comprises three cases of buyersupplier contractual relationships: one using a promotion frame, one using a prevention frame, and one using a 'hybrid' frame (i.e., including both bonus- and penalty-based incentives).

The study contributes to contracting research by showing how differently framed performance incentives affect suppliers' responses and buyer-supplier relations. It does so by drawing on theories from cognitive and social psychology stressing the psychological impact of contracts (Weber and Mayer, 2011; Schepker et al., 2014). In addition, the study extends the limited empirical literature on contract framing effects (e.g., Weber et al., 2011) by: a) examining the effects of hybrid-framed incentives on supplier expectations and subsequent responses, b) demonstrating that promotion- and hybrid-framed incentives do not by default lead to productive supplier responses, and uncovering several moderating factors pertaining to contractual clarity, and c) showing that the framing of provisions should be considered in joint with the clarity and overarching purpose of the contract so as to elicit appropriate supplier responses. The paper offers managerial insights regarding a strategic approach to contract framing considering different types of supplier relationships. It also highlights factors influencing the effective design of promotion- and hybrid-framed incentives. 
The remainder of this paper is organised as follows. First, we present and discuss our analytical framework which is informed by Regulatory Focus Theory (Higgins, 1998, 1997) and Expectation Violation Theory (Bettencourt et al., 1997; Burgoon, 1993). Following Weber and Mayer (2011), we adopt these perspectives to analyse the effects of different types of contract frames on the focal exchange and the underlying relationship. We then explain our research design, after which we analyse our cases and discuss the cross-case findings. We conclude by drawing out theoretical and managerial implications, limitations, and future research avenues.

\section{Theoretical background}

Recent contracting research demonstrates a shift in attention from contract structure as a safeguard to economic risk, to contract functionality and its effects on coordination and adaptation (Schepker et al., 2014). It suggests that contractual provisions of various natures may have different effects on the specific exchange and the ongoing buyer-supplier relationship (Cao and Lumineau, 2015; Schepker et al., 2014). Mayer and Argyres (2004), for example, found that while the use of enforcement clauses does not necessarily damage the development of buyer-supplier relationships, the alignment of expectations is not necessarily benign. Vanneste and Puranam (2010), in a similar vein, argue that provisions that serve as coordination mechanisms do not invoke distrust, while provisions that fulfil the safeguarding function may inhibit the development of trust. Weber et al. (2011) found that a shorter-term contract with an extendibility option appears to be perceived as a positive incentive and more effective in managing exchange relationships than a longer-term contract with an early termination clause. Schilke and Lumineau (2017) find that control and coordination functions of contracts, which are suggested with different contractual frames, have a distinct impact on the relationship. 
Underlying these differing effects is that contracts do not only impact an exchange economically, but also psychologically (Weber and Mayer, 2011).

Such a psychological impact is underplayed in the generic contracting and the more specific PBC literatures, regardless of the theoretical perspective (Transaction Cost Economics (TCE) (Williamson, 1985), relational contracting (MacNeil, 1980), Agency Theory (AT) (Eisenhardt, 1989)) adopted $^{1}$. Explicating the role of framing in contract design is important as it helps us to understand why certain relationship outcomes are achieved (Weber, 2017).

To address the psychological impact of contracts, we draw on Regulatory Focus Theory (RFT) (Higgins, 1998) and Expectation Violation Theory (EVT) (Burgoon, 1993) to explain why different contract frames affect the exchange and the buyer-supplier relationship differently. In short, RFT suggests that contractual provisions can be framed either as a loss or as a gain (Higgins, 1998; Roney et al., 1995; Tykocinski et al., 1994) and that each of these frames will be interpreted differently by the contracted party. These interpretations lead to very different expectations for exchange outcomes and the relationship between the exchange partners (Weber and Mayer, 2011), thereby inducing certain supplier responses. EVT (Bettencourt et al., 1997; Jussim et al., 1987; Jackson et al., 1993; Kernaham et al., 2000; Burgoon, 1993) subsequently suggests that meeting or violating expectations set by contractual frame during contract execution further affects the exchange and the ongoing relationship (Weber and Mayer, 2011). In other words, what happens during the exchange and in the ongoing relationship will either be in line with initial anticipations as elicited by the contract frame, or not.

RFT and EVT inform our analytical framework (see Table 1) which comprise the following constructs: 1) framing of contractual performance incentives i.e., promotion versus

\footnotetext{
${ }^{1}$ Although none of these conventional contracting theories explicitly addresses the notion of framing, this is often implicitly present. We return to this point in the discussion section.
} 
prevention frame (derived from RFT); 2) the ex-ante expectations regarding the exchange and the relationship set by different types of frames (derived from RFT); 3) supplier behavioural and relational responses triggered (derived from RFT); and 4) meeting or violating the expectations set by the type of contractual framing (derived from EVT). In what follows we elaborate on these constructs.

Insert Table 1 about here.

Under a prevention frame, contractual performance incentives are framed as a loss and parties interpret a performance target as a minimum that must be achieved. Performance incentives take the form of negative motivation, i.e., the use of penalties in case performance targets are not achieved. RFT suggests that the supplier wishes to avoid not meeting the targets and incurring the penalty, and therefore responds by displaying vigilant behaviour during the exchange, aimed solely at meeting the minimum performance. With regard to the relationship, a prevention frame leads the supplier to emphasise negative aspects of the relationship, which triggers the relational response to keep the counterpart at arm's length (Cao and Lumineau, 2015). RFT also suggests that the prevention contract sets, overall, negative ex-ante expectations. These are based on anticipations for impersonal behaviours during the exchange and transactional relationships focusing mostly on the letter of the contract.

In contrast, under a promotion frame, parties view a performance target as a maximum that may be achieved (Weber and Mayer, 2011). Performance incentives take the form of positive motivation, i.e., receiving a bonus in case performance targets are achieved or exceeded. The supplier will actively seek to achieve the objectives, and hence, according to RFT, responses during the exchange will involve the creativity and flexibility needed to achieve an aspirational objective (Weber et al., 2011). Moreover, at the relationship level, a promotion 
frame draws more attention to positive relationship aspects, leading the supplier to emphasise cooperation and inducing responses aimed at the development of close, personal, and trusting relationships (Schepker et al., 2014). Ex-ante expectations set by a promotion frame are, overall, positive. That is, they include positive exchange behaviours that go beyond the letter of the contract, and close, nurturing and interactive relationships, as suggested by RFT.

EVT specifically focuses on whether ex-ante expectations that are set by the contract frame are met or violated during contract execution. Under a prevention frame, meeting ex-ante expectations for impersonal behaviours and transactional relationships will reinforce the business-like character of the exchange, while violating such expectations will trigger high partner satisfaction and closer relationships. Under a promotion frame, meeting ex-ante expectations for behaviours that go beyond the letter of the contract and close, nurturing relationships will reinforce the positive, close and cooperative relationship that exists. Violating such expectations, however, will undermine the relationship, leading to partner dissatisfaction and possibly termination of the contractual relationship.

The research design is explained in detail next.

\section{Research method}

Empirical evidence regarding the impact of framing of contracts (and specifically performance incentives) on suppliers' behavioural and relational responses is limited to date. A case-based research design allows developing an in-depth understanding of contract framing effects and elaborating existing theory (Ketokivi and Choi, 2014) on the role of framing in buyer-supplier contractual relationships by: a) identifying context-specific framing objects (e.g. performance indicators and targets, and incentive structures) and, b) stressing factors moderating the effects of promotion (e.g. realism of performance targets and salience of bonus payments), or 'hybrid' frames (e.g. proportionality of bonus /malus). Another argument for doing case-based research 
is that case studies are particularly useful for collecting detailed data on formal contracts (Lumineau et al., 2011). Indeed, access to copies of key contractual documents (e.g. service level agreements and payment mechanisms) proved a crucial source of evidence for understanding how performance incentives were framed, and provided details of the payment structure and associated gain-share and penalty-based schemes.

Our empirical study entails a multiple-case research design (Yin, 2009) involving three in-depth case studies of contractual relationships in the context of logistics outsourcing (see Table 2). The logistics industry is considered an appropriate example context given the increasing adoption of pay-for-performance incentives and the challenges associated with designing effective performance incentive systems that elicit productive supplier responses i.e., behaviours in line with buying firms' interests (e.g., Selviaridis and Norrman, 2015). The three cases were selected using theoretically motivated (Dubois and Araujo, 2007) purposive sampling (Patton, 1990): while the payment mechanism in Case A defined a bonus for performance achievement, the contract in Case B stipulated penalties for non-performance. The contract in Case $\mathrm{C}$ catered for both bonus and penalty payments. Hence, the three cases were expected to be associated with differing supplier behavioural and relational responses.

Insert Table 2 about here.

Data were collected through 38 semi-structured interviews with managers of supplier companies, and analysis of 43 organisational documents, including copies of the contracts. The interviewees spanned multiple functional disciplines including Business Development (BD), Key Account Management (KAM), Operations and Legal. Although supplier companies and the views of their managers were in focus, Case $\mathrm{C}$ also entails interviews with the Logistics and Supply managers of the buyer firm with the purpose of clarifying specific aspects of the agreed 
balanced scorecard that these managers initially designed. Appendix A provides further details on the interviewees across the three cases.

The semi-structured interviews had an average duration of approximately an hour, and covered multiple themes including the formation and evolution of the buyer-supplier relationships, the exchange goals, the rationale for introducing performance incentives, the details of designing and framing them, and the supplier behavioural and relational responses they instigated. The interviews helped to elicit information regarding supplier expectations as set by the contractual frame, whether these expectations were met, and any associated emotional reactions (e.g. frustration or a sense of unfairness). The inclusion of open-ended questions (Miles and Huberman, 1994) allowed also capturing additional emerging themes such as the role of contractual clarity e.g. regarding KPI definition and attributability of performance results. Appendix B presents the interview guide.

The interviewee accounts were complemented and triangulated by accessing and analysing key documents (Marshall and Rossman, 1999) including formal agreements, contractual payment mechanisms and performance evaluation records. Analysis of these documents and specifically of the relevant contractual provisions (e.g., performance- and payment-related clauses) provided clear indications for how they were framed, i.e., in promotion or prevention terms (Weber and Mayer, 2011). Excerpts from the formal contracts were also referred to during the interviews and discussed with managers to seek clarifications, and to capture their views on the designed performance incentives, their effectiveness, and any related challenges.

The quality of the case studies was assessed by applying specific criteria and measures to address internal validity, construct validity, external validity and reliability issues (Yin, 2009). Table 3 shows how each criterion was met following recommendations provided by Gibbert $e t$ al. (2008) and Eisenhardt and Graebner (2007). 
Insert Table 3 about here.

Data coding and analysis was conducted manually and much in parallel with data collection following recommendations by Barratt et al. (2011) and Miles and Huberman (1994). Data coding initially focused on our key constructs, but additional themes and codes emerged from the interviews, e.g., regarding the realism of performance targets and the proportionality of bonus and penalty payments. Open codes (e.g. 'bonus payment', 'gain-share', and 'penalty payment') were initially assigned to interview transcripts and document sections, and these were later grouped into higher categories (e.g. 'promotion-framed incentives', 'preventionframed incentives') using axial coding procedures (Strauss and Corbin, 1990). Overall, data analysis was an iterative process with codes being refined by moving back and forth between data, the analytical framework and the cross-case analysis (Ragin, 1992).

\section{Findings}

This section presents the findings of the within-case analyses. Case A and Case B involved a promotion and a prevention frame respectively, and clear differences were found in terms of supplier responses and relationship dynamics. The contractual incentives in Case $\mathrm{C}$ were framed both in promotion and prevention terms, which, nonetheless, triggered predominantly positive supplier behavioural and relational responses. The key findings per case are summarised in Table 4. Whenever relevant, we highlight in the following additional important aspects particularly with respect to the buying firms' view of the supplier relationships in focus, suppliers' contractual relationships with customers other than the buying firms in focus, and any differing perceptions within and /or between the buying and supplying firms.

Insert Table 4 about here. 


\subsection{Case A: promotion-framed performance incentives}

Supplier A's payment is linked to product availability and supply chain cost reduction targets in the form of a gain-share mechanism. The agreed 'fixed-price-plus-incentive-fee' payment mechanism (Table 2) is promotion-oriented since the incentive fee is framed as a financial bonus, and there are no financial penalties connected to performance targets. This is also confirmed by the studied records of buyer-supplier meetings referring to "[a] bonus system in relation to operational performance and cost". Earlier versions of the contract had also stressed the joint intention to establish a gain-share mechanism: "The Parties agree to continue their discussions regarding a gain sharing model as a means to incentivize actions for cost reduction by the sharing of achieved savings over an agreed period of time" (excerpt from the contract payment clause). The parties deemed this necessary in order to (re)align their incentives given that Buyer A's shifting emphasis towards cost efficiency had meant that the 'cost-plusmanagement-fee' included in the previous version of the contract payment clause would have created an incentive conflict, i.e. the supplier would be losing revenue while reducing supply chain costs.

The agreed form of the incentive fee resulted from a negotiation process aimed at tackling two issues on which Buyer A and Supplier A initially had differing views. First, whether to link the incentive fee directly to cost reduction targets, or to volume increase outcomes as a surrogate metric of supply chain efficiency. The latter option was based on the assumption that supply chain efficiency would reduce product prices at stores and thus lead to increased sales and logistics volumes. In the end, parties agreed to link the incentive fee directly to cost reduction targets. Second, whether the incentive fee would also include a penalty for under-performance. Buyer A initially proposed the inclusion of both a penalty and a bonus payment, which Supplier A rejected on the ground that it was too risky since there were far too many uncontrollable factors influencing the achievement of cost saving targets e.g.: "From our point of view 
penalties are excluded" (Supplier A's BD Manager). Crucially, Supplier A interviewees stressed that the inclusion of penalties would have created a 'finger-pointing' culture and harmed the relationship, as the supplier would be trying to defend itself for any performance failures attributable to the customer or third parties. Subsequently, the parties agreed to a bonusonly incentive, which was linked to minimum product availability targets.

Ex-ante expectations. The resulting bonus-based incentives (Table 2) set positive supplier expectations particularly regarding the alignment of interests with the buyer and a collaborative effort to improve cost efficiency and service performance. Specifically, the agreed gain-share scheme helped to establish a joint aspirational vision and goal towards increased supply chain efficiency and, through that, further business growth. From Buyer A's perspective, the creation of this joint aspiration was important as they were single-sourcing logistics services and they were seeing the supplier as a strategic partner that they needed to align with. Supplier A interviewees stressed their positive expectations regarding the gain-share arrangement: "We need to align our goals and expectations and what we would like to achieve and then it's about acting as one team with one focus! And then it's about win-win-win...if you are able to drive cost out of the system then you are able to get the benefit for the consumers and then you have gained a competitive advantage...people buy more products and then we are getting more money or more volumes to distribute the fixed cost” (Supplier A's Managing Director).

Overall, there was a common view of such expectations at Supplier A despite certain BD managers' concerns regarding the feasibility of bonus achievement (see below). Supplier A interviewees converged to the suggestion that the cost efficiency goal would create a virtuous circle. As Supplier A's Operations Director exemplified: “[...] if this product costs 10 euro to get from a wholesaler and we move it to our supply chain and it costs 8 euro, then of course it's the same product, it's just more efficient to do it in our way, then of course they [Buyer A] 
can lower their landed price to their customers [...] And if they bring the price down, they sell more! That's the mentality".

Supplier responses. The bonus /gain-share incited Supplier A to direct its attention to the supply chain efficiency goal of Buyer A. As such, it contributed to (re)alignment of the counterparts' incentives and helped to reinforce their collaborative relationship.

Regarding behavioural responses specifically, the supplier emphasised cooperation. Supplier A's BD Manager suggested that "the version [of the payment mechanism] we have now emphasises changes to make right decisions and make improvements [...], up front planning and joint effort to determine what should be taken into account to achieve the set cost saving target". The promotion frame also enabled a flexible framework of cooperation. Indeed, Supplier A managers emphasised the need for flexibility to work towards the common goal and be prepared to adapt the contractual incentives if these were not helpful. As Supplier A's Managing Director put it: "[...] let's do that for three months and then what we expect is this... and if this goes to the wrong direction and we make more money, that's not what we want and we can correct that! I mean it should be based on transparency and trust...this is what we want to have as a margin, at least as basis, and then let's test this model and then we can revert, because then you can build trust, and we see things happening in the right direction".

Regarding Supplier A's relational responses, the gain-share mechanism instigated a collaborative working atmosphere based on trust and the two organisations worked closely to identify opportunities for supply chain efficiencies without compromising service levels. Crucially enough, this also entailed Buyer A's active involvement and cooperation, since efficiency of logistics operations required changes in the way stores behaved and operated e.g.: "We will need their [Buyer A] support, absolutely, because we can't impact much without their changes [...] if we don't change the ways the stores order or reduce frequencies of deliveries 
[...] there cannot be the savings they are looking for without a change of methodology, a change of thinking” (Supplier A’s Operations Director).

Meeting/ violating expectations. The promotion frame initially set positive expectations for buyer-supplier collaboration, and these were, on the whole, met and led to supplier responses that were in line with Buyer A's interests. However, Supplier A interviewees also expressed their worries and reservations about the cost savings split and the intensity of performance targets which the bonus scheme was going to be linked to. Supplier A managers pointed out that the contract did not accurately reflect Buyer A's expectations regarding performance goals since the cost reduction target was to be revised and agreed annually (against the previous year's baseline). This created supplier concerns regarding the sustainability of performance improvements and the intensity of performance targets. As one of Supplier A's BD Managers explained at the time: It depends how [the buyer] sets it; if they say any savings will be shared 80/20, then we always have an incentive to save. If they say you have to reach target 97 and then you get 5 million, then if we are uncomfortable in saving 97 we should do other things". Indeed, the agreed contract stipulates that the incentive fee is paid out only if the supplier achieves $90 \%$ of the annual target, and only if product availability performance does not drop below $83 \%$ of the annual target. Supplier A interviewees stressed the importance of securing a 'fixed fee' element that would enable financial viability of the business irrespective of the potential bonus payment: "They [Buyer A] have the mentality that we need to reach almost $100 \%$ to get a bonus or nothing, which I think is OK depending on the target and how achievable it is. If they are not achievable, then the bonus will be something that we won't budget for" (Supplier A's BD Manager). The above suggest that Supplier A's exact responses were somewhat influenced by the detailed design of the bonus scheme, even though the positive ex-ante expectations were overall met. 


\subsection{Case B: prevention-framed performance incentives}

The contract in Case B does not include a bonus for achieving or exceeding the specified performance targets. Rather, it stipulates standard penalties for Supplier B non-performance in terms of delayed deliveries and product damage or loss (Table 2). The contractual incentives in this case were clearly framed in prevention terms as the agreement referred to financial penalties only. This was also confirmed by Supplier B's Global KAM who stated that "we have some penalty clauses where we are responsible for direct loss of transport failures, but not indirect effects [of such failures]". In-depth study of the relevant contractual provisions revealed that they were framed in terms of losses Supplier B would incur in the event of service failures. The 'non-performance clause' of the agreement stipulated that: “The Supplier agrees to compensate [Buyer B] Ex Gratia, for non-performance of a defined part of the Assignment, the same falling outside [Buyer B's] General Conditions for Services, mandatory laws, rules, conventions and regulations, applicable on this Service Agreement. The compensation in accordance with this Clause is limited to one (1) Basic Amount per incident or in total ten (10) [units] per year”.

Ex-ante expectations. The prevention frame made Supplier B expect a non-collaborative relationship atmosphere and close monitoring by Buyer B. Such expectations were shared across all Supplier B interviewees who, more broadly, converged in their reluctance to accept penalty-based incentives especially when these had not been accompanied by bonus payments e.g.: "If we do it [introduce penalties], then there needs to be bonus for performance and I think that the customer doesn't like that" (Supplier B's Internal Control Manager). Notwithstanding that, the interviews also revealed differing views on the use of performance incentives more generally - while managers from BD and KAM functions were emphasising more the potential rewards to be had, interviewees from other functions (e.g. Operations, Finance and Legal) were more mindful of the associated financial risks. 
The generic reluctance to accept penalties for non-performance without the corresponding rewards for performance achievement was reflected in the way Supplier B contracted with some of its other customers: analysis of two additional customer contracts that, interestingly enough, were written following Supplier B's contract template, suggests that penalties (as well as bonuses) were excluded. As several Supplier B interviewees explained, this was because penalties were perceived as financially risky, a perception that was exacerbated by the typical resistance of customers to bonus-based incentives as these translated into increased customer costs (which are not acceptable in the highly competitive market for logistics services). Nonetheless, in the contractual relationship with Buyer B, who had high bargaining power, Supplier B had no option but to accept penalties.

From a Buyer B's perspective, the relationship with Supplier B was seen as transactional in nature. This was reflected in the contract, which put emphasis on safeguarding against potential supplier opportunism (via the stipulated penalties) and offered no incentives for service performance improvement or innovation. The relevant contractual provisions also stressed the need for cost transparency and competitive service prices as evidenced, for instance, in the 'supplier compensation' contract clause: “The Supplier agrees to present the cost for the Service in a Cost Split Model in order for [Buyer B] to understand the cost structure with the purpose to drive total cost from the system". Supplier B interviewees perceived these provisions as setting a minimal goal and signalling that Buyer B was " [...] chasing cost a lot. And now they are searching for competitive prices in the market"' (Supplier B's Internal Control Manager).

The following excerpt from the 'contractual specification for packaging services' (appendix to the master agreement) also attests to Buyer B's vigilant attitude and emphasis on controlling Supplier B's behaviour: "It is understood by the Supplier that time has been an essential precondition on which [Buyer B] has entered into this Agreement and it is, thus, of 
utmost importance that the Supplier manages to meet the KPIs and carry out the delivery services and other related services timely. The Supplier shall be liable for that the Packaging are loaded, stowed, secured and anchored in accordance with all applicable laws, regulations and other governmental rules and in such way that no loss or damage to the Packaging, person, property or environment will arise during transportation or at unloading”.

Supplier responses. The emphasis on close monitoring of Supplier B's behaviour and on the penalties for non-performance demotivated Supplier B from initiating service improvements.

Supplier B managers suggested that this was a missed opportunity, and that it was creating a competitive relationship atmosphere. They openly expressed their disappointment about Buyer B's over-emphasis on cost, which prevented Supplier B to focus on continuous improvement and customer value. Supplier B's Global KAM complained, for example: “they want cost-based pricing to benchmark us to our competitors. But they shouldn't be comparing apples with pears as they do most of the times [...] What about the rest of the service we provide; this is not for free! So we have different mind sets, we come from a service background and they come from direct material, they want to work through benchmarks to get confident in contract negotiations to ensure they do a good purchasing job”.

Regarding behavioural responses in particular, Supplier B adopted a vigilant attitude and was largely pre-occupied with mitigating its financial risk and losses in connection to the penalties clause. This was done by negotiating firm limits to the penalties and financial liabilities associated with performance failures. Supplier B demanded that performance-related penalties referred only to direct damages to Buyer B, and did not cover any indirect losses that Buyer B incurred as a result of failed deliveries or lost/damaged cargo. This was firmly expressed by Supplier B's Legal Counsel who exemplified: "[...] if there is a delay the only liability for the carrier is to pay compensation of the original freight value, not indirect or 
consequential damages [...] so if we are delayed in the delivery of machines to the Gothenburg factory, then we just pay compensation for the original freight transport".

In terms of relational responses, Supplier B interviewees perceived Buyer B's focus on cost transparency and competitive prices, as reflected in the contract, as harming the relationship. As Supplier B's Global KAM admitted at the time, "we need to revitalise the business relationship because we understand that it is not healthy right now”. Several Supplier B interviewees confirmed that the exchange relationship had a transactional focus and stressed the buyer's lack of trust towards them. Supplier B's Internal Control Manager explained that "the main challenge is to offer them [Buyer B] transparency. Because they want an open-book philosophy and we haven't been good at offering that. So there are issues around trust and whether the prices we quote them are the correct ones, [Buyer B's] people wonder".

Meeting /violating expectations. These behavioural and relational responses reinforced the safeguarding attitude from both sides and confirmed the negative expectations that the prevention-framed contract set initially. Buyer B's goal to control costs and prices was also in direct contradiction with Supplier B's strategic intent on implementing value-based selling and contracting with its customers. As Supplier B's Vice President of Global BD explained, “I always want us to make as much money as possible and that's why we move away from costbased pricing by explaining to our customers the value proposition we bring to their business, and by that charging a higher price".

The negative Supplier B responses prompted by the prevention-oriented frame eventually led to the termination of the contractual relationship in 2014. Although Buyer B initiated the contract termination process based on Supplier B's failure to meet its requirements (particularly regarding cost transparency), the main underlying reason for contract termination appeared to be Supplier B's frustration with Buyer B's emphasis on minimal, non-aspirational goals. By way of contrast, Supplier B interviewees pointed at the contractual relationship with another 
customer where a gain-share for logistics efficiency improvements was discussed: "[...] on the basis of 50-50 split of cost savings we file for, on the basis that we jointly look for such savings. So we have a jointly defined speaking partner from the customer side, so rather than just being us looking internally, they need to meet us halfway" (Supplier B's BD General Manager, Outbound). In that case, the promotion-oriented frame appears to have triggered a positive supplier response, which has contributed to incentive alignment and a collaborative relationship, as also suggested by the BD manager above: I'd say that they [Buyer X] are one of our best customers [...] and they want us to take cost out of their system".

\subsection{Case C: 'hybrid'-framed performance incentives}

Supplier C's payment is linked to performance through a bonus and malus scheme, and a separate gain-share for cost savings resulting from supplier-led service innovations (Table 2). The contractual incentives were therefore designed using a 'hybrid' frame including both elements of promotion (bonus and gain-share) and prevention (penalty). The relevant clause included in the contractual service level agreement (SLA) stipulated that: "In connection to the services provided the supplier shall follow up and report mutually agreed KPIs in a balanced scorecard [...]. The supplier target is linked to an incentive model and the fees paid by the client will be dependent on the results of the balanced scorecard". This scorecard essentially translated KPI results into a scaled score ranging between 1 and 5, with the latter being the maximum (i.e., highest performance). The balanced scorecard was linked both to bonus and penalty payments (Table 2). For instance, a performance score of 5 would entail a Supplier C bonus of $3 \%$ of the annual service fees, whereas a score of 2 would entail a penalty of $0.5 \%$ of the annual fees. In addition, the SLA specified a gain-share model whereby Supplier C is required to "proactively initiate new solutions which enable logistics costs reduction" (excerpt 
from the contractual SLA document). The gain-share depended on the percentage of cost savings achieved against Buyer C's annual target (Table 2).

Ex-ante expectations. The 'hybrid' frame set expectations for collaboration, proactivity and creativity and Supplier C-led innovation, reflecting an emphasis on a joint aspirational ('may-be-achieved') goal to continuously improve service delivery. From Buyer C's perspective, Supplier C was considered a logistics partner whom Buyer C needed to collaborate closely with to introduce service process innovations that would help increase efficiency. More broadly, Buyer C's structured approach to segmenting its logistics service suppliers ('strategic'; 'preferred'; and 'others') had implications for contract design, in the sense that the inclusion of gain-share for innovation-driven cost savings applied only to strategic suppliers. As Buyer C's Global Supply Manager put it, "we are so interlinked and we don't treat them like a supplier, but like a partner. With other suppliers we don't have that [gain-share]".

The aspired service innovations could also be transferred to Supplier C's other customers, and hence, Supplier C interviewees viewed the realisation of innovation as an objective with potential benefits beyond the immediate ones specified in the gain-share clause. The balanced scorecard, which the bonus and malus provision was tied to, also created a framework for regular performance monitoring. Specifically, this provision reflected the need for Supplier C to improve service performance and meet freight cost reduction targets set by Buyer C, to be able to stay competitive against other potential suppliers. This 'must-be-met' goal complemented the aspirational objective of proactive improvement.

Despite the 'hybrid' framing (promotion and prevention elements), there was a common view and perception across all Supplier C interviewees that the contractual incentive provisions were, overall, articulated in terms of gain. According to the supplier's Global Key Account Manager (KAM) for instance, "[Buyer C] needed us to support them with cost efficiency and we needed a tool, so that was the SLA with the penalty and bonus scheme and we would have 
something to gain as well. We have been working with KPIs for many years, but we never had those linked to payment".

Supplier responses. Because of the greater emphasis on rewarding proactive performance and innovation compared to penalising under-performance (see Table 2), Supplier C's managers perceived the introduced performance incentives in a positive light.

Regarding behavioural responses, the bonus and gain-share mechanisms instigated Supplier C creativity and proactivity and helped in aligning Supplier C's goals and incentives with those of Buyer C. Especially in relation to the gain-share mechanism for innovationrelated cost savings, Supplier C clearly put increased effort in proactively identifying potential service process innovations and establishing internally structured processes for creating and documenting innovative ideas. As Supplier C's Global KAM stressed, "This [the SLA] has helped to change our mentality and to think in terms of performance improvement. And it also offers the opportunity to have a dialogue with the customer and other parties in the supply chain to understand what is needed to achieve the targets".

In terms of relational responses, the emphasis put on the bonus and gain-share provisions appears to have strengthened the buyer-supplier collaboration towards the achievement of the jointly defined aspirational goal for ongoing service improvement. As Buyer C's Global Supply Manager confirmed, "It [SLA] has been an absolutely positive experience and we got their [Supplier C's] attention, we are seeing a change in their mind set and it is quite nice to see that they are focusing on hitting the targets, generating ideas for improvement".

Meeting /violating expectations. Supplier C's motivation to proactively improve service delivery and innovate confirmed the initial positive expectations that the hybrid-framed incentives set, which were overall met. However, there were certain incidents where the implementation of the contractual incentives led to temporary violation of Supplier C's expectations. In addition, these incidents also revealed somewhat differing views between 
Supplier C and Buyer C with respect to: a) how Supplier C's innovative ideas would be recognised and credited, and b) what customer inputs were required to co-produce the agreed service outcomes. These aspects were evident particularly when Supplier C was asked to pay a financial penalty for under-performance at the end of the first year these incentives had been in force. Supplier C interviewees vented their frustration at the time because the decisions and actions of Buyer $\mathrm{C}$ had an impact on performance e.g. in terms of carbon emissions reduction and on-time deliveries. For example, Supplier C's Air and Outsourcing Manager complained that "[Buyer C] needs to place the bookings earlier, to plan this and that, to provide us with the packing lists and all the correct information [...] they [Buyer C] have problems to get the instructions from their customers, they are pushing them to get the information in good time so that we can plan the transports". Such Buyer C responsibilities were not explicitly specified in the balanced scorecard and the related contractual incentives. In a similar vein, Supplier C interviewees expressed their disappointment about the lack of a clear mechanism for attributing innovative ideas to Supplier C. This meant that in many instances Buyer C had claimed ownership of innovations and related cost savings. These events appeared to have temporarily violated Supplier C's positive expectations and caused some harm to the relationship.

These Supplier C concerns and complaints were addressed as Buyer C acknowledged that under-performance in some KPIs (e.g. carbon emissions target and deliveries accuracy) was due to factors beyond Supplier C's control. Buyer C, as a result, decided to relieve the supplier from the penalty payment, as explained by Buyer C's Outbound Logistics Manager: "So we didn't want to get the penalty since the savings were far higher than expected [...] and performance in this respect [carbon emissions] was affected by decisions of market companies [end customers] regarding air freight use”. Buyer C's reaction constituted a positive violation of Supplier C's expectation to pay the stipulated penalty and helped to strengthen collaborative efforts to achieve the set goals. As Supplier C's Global KAM confirmed, “[...] it was really a 
suggestion by [Buyer C] that we didn't have to pay the penalty. The collaborative relationship mattered more, and it was also the first year of implementing [the performance incentives]".

These hurdles and the associated lessons learned triggered a process of renegotiation to refine and adjust the 'hybrid' incentives in terms of: a) adjusting the definition of some KPIs (e.g. "logistics cost reduction" and "deliveries accuracy") and their weights, b) explicating all Buyer $\mathrm{C}$ actions influencing carbon emissions and excluding those from the calculation of the incentive fee, and c) agreeing on a process for documenting Supplier C's innovations resulting in cost savings. These contract adjustments reinstated the collaborative atmosphere and contributed to improved alignment of buyer and supplier goals, as also suggested by Buyer C's Outbound Logistics Manager: “It's been positive and it's been a learning process for both sides. And we can improve it further, the KPIs can be improved, it's not the highest level but the mind-set is there now. And for me the most important and positive thing is to see that they are asking to increase the weight of the KPI connected to innovative ideas".

\section{Discussion}

Cross-case findings suggest that promotion-framed incentives lead to productive behavioural and relational supplier responses and improve relationships as initial positive expectations (e.g. for collaboration) are overall met, while prevention-framed incentives result in unproductive supplier responses and deteriorating relationships as initial negative expectations (e.g. for an adversarial working atmosphere) are also met. While this provides a confirmation of Weber and Mayer's (2011) conceptual analysis, our study extends that by highlighting several emergent findings on the effects of hybrid-framed incentives and of contract framing more broadly.

Firstly, hybrid-framed incentives can lead to productive supplier responses and improve relations when positive ex-ante expectations are met. When such positive expectations are not met (e.g. in specific incidents), further interactive work is required to refine contractual 
provisions to re-instate alignment and perceived fairness in the spirit of continuing a valued relationship. Secondly, whether hybrid-framed incentives set positive expectations (or not) in the first place depends on their detailed design, particularly in terms of the proportionality (relative salience) of bonuses versus penalties. This highlights the importance of appropriately balancing risks and rewards (Hypko et al., 2010) so that the supplier perceives the designed incentives as positive and fair. Fairness pertains not only to actual cash flows but also to emphasis being put by the buyer on rewards for performance achievement (see weighting of bonus/malus scheme in Case C), which signals to the supplier how the contract is to be perceived and sets supplier expectations accordingly. Thus, the proportionality of penalties visà-vis bonuses (Sols et al., 2007; Selviaridis and Spring, 2018) needs to be considered when promotion- and prevention-framed incentives are used in combination. Overall, we propose:

P1: The positive effect of hybrid-framed incentives on supplier expectations is moderated by the proportionality (relative salience) of penalties and bonus payments.

Thirdly, exact supplier behavioural and relational responses to promotion- and hybridframed incentives are contingent on several factors pertaining to contractual clarity. These include the following: a) clearly defined inputs of the buyer and third parties into service delivery, b) clearly defined uncontrollable factors affecting performance, c) ability to clearly attribute performance results to specific actors or factors, d) clarity regarding the evolution of performance targets, and e) feasibility /realism of performance targets. In other words, promotion-framed, as well as hybrid-framed incentives that set positive expectations, do not by default lead to productive supplier responses as suggested in the literature (e.g., Cao and Lumineau, 2015). Case A (promotion frame) illustrates Supplier A's concerns regarding uncertainty of cost reduction targets in subsequent years, while Case $\mathrm{C}$ (hybrid frame) illustrates how lack of clarity regarding definition of KPIs and performance attribution led to supplier frustration and temporarily threatened the relationship. In such situations, suppliers may be less 
motivated to work hard, not least because it is less likely that any bonus would do justice to their efforts (Selviaridis and Norrman, 2015).

What seems to be necessary to trigger productive supplier responses is contractual clarity to mitigate uncertainty and establish an exchange framework that is perceived as fair (Schilke and Lumineau, 2017). The consequences of contracts do not only strongly depend on the adopted frame, but also on the interpretation of the contract design and management aspects highlighted above. We therefore propose:

P2: The positive effect of promotion- and hybrid-framed incentives on supplier responses is moderated by contractual clarity regarding responsibilities and inputs of buyer and third parties, uncontrollable factors influencing performance, attributability of performance, and feasibility and evolution of performance targets.

Fourthly, differential contract frames (Schepker et al., 2014) can be used strategically by buying firms depending on the type of supplier relationship in focus. Specifically, preventionframed incentives can be more appropriate for supplier relationships perceived as transactional, while promotion- or hybrid-framed incentives can be used in collaborative supplier relations. For example, a penalty-scheme such as the one in focus in Case B does not particularly lend itself for relationship improvement. For this reason, the fact that the relationship did not improve (in fact it deteriorated) should be no surprise. In contrast, the gain-share scheme that features in Case A aided to establishing joint objectives, which Buyer A considered important having opted for single sourcing and thereby making Supplier A its strategic partner. As such, the gain-share scheme facilitated not only the realisation of joint objectives, but also the establishment of a closely collaborative relationship. In the same vein, a prevention-framed is not necessarily a counter-productive choice in cases of transactional relations with less important suppliers.

These observations suggest that the overarching purpose of the contract has implications 
for which frame is most suitable; i.e., the one that enables the achievement of this overarching purpose. Hence, we propose:

P3: The effects of contract framing on supplier responses are moderated by the overarching purpose of the contract: prevention-framed incentives can be more effective to control suppliers and mitigate opportunism in transactional supplier relations, while promotion- or hybrid-framed incentives can be more effective to drive collaboration and winwin outcomes in strategic supplier relations.

The above findings suggest that beyond the impact of contract framing (Weber and Mayer, 2011), the clarity and overarching purpose of the contract also play a role in influencing supplier behavioural and relational responses. All three elements appear to interact, and it is this interplay that determines the effectiveness of the exchange and the buyer-supplier relationship more broadly ${ }^{2}$.

\subsection{Theoretical and managerial implications}

Our study presents two important theoretical implications: one regarding the notion of framing as an element of contracting, and one regarding the theoretical lenses typically used to study contracting. On the notion of framing, our study contributes to the limited body of empirical research on contract framing effects (Weber et al., 2011; Weber, 2017) in multiple ways. Crucially, our study examines the effects of hybrid-framed incentives on supplier expectations and subsequent behavioural and relational responses and uncovers the conditions upon which combinations of bonus- and penalty-based incentives can be interpreted as predominantly positive by suppliers, an issue that has remained unexplored hitherto (Weber, 2017). The study also provides a nuanced understanding of the framing of performance incentives and related challenges e.g., regarding proportionality of bonuses and penalties. In

\footnotetext{
${ }^{2} \mathrm{We}$ are indebted to one of the anonymous reviewers for raising this point.
} 
particular, it demonstrates that contract framing requires thorough consideration, as promotionand hybrid-framed provisions do not by default have positive effects the extant literature suggests (e.g., Schepker et al., 2014). Our empirical research uncovered several moderating factors that collectively stress the importance of contractual clarity (see P2).

Finally, our study extends the existing literature by showing that contract framing, and the clarity and the overarching purpose of the contract should be considered jointly when seeking to elicit specific supplier responses. The vigilant behaviour triggered by a preventionframe may be harmful when applied in contracts with strategic suppliers, but it may be harmless and even effective when adopted for transactional relationships. Alternatively, eliciting creativity by means of promotion-framed incentives may not be effective in these arm's length supplier relationships. As such, the notion of framing warrants analysis both at the level of specific contractual provisions and at the level of the overarching contract purpose.

Regarding theoretical lenses adopted in the study of contracting, we suggest that RFT and EVT help to extend our theoretical understanding of contract design and its effects in that it stresses the critical role of framing and the management of expectations that different frames set. Neither TCE nor AT explicitly acknowledge nor address the psychological impact of contracts and the role of framing more specifically. Many TCE-informed contracting studies implicitly assume such a prevention frame (see a.o. the work on take-or-pay provisions by DeCanio and Frech, 1993; Hubbard and Weiner, 1986; Masten and Crocker, 1985). Both AT’s behaviour-based and outcome-based contracts seem to focus on avoiding unproductive supplier responses (i.e., opportunism), which again implies a prevention frame. Our empirical study, however, revealed that bonus provisions and /or gain-share schemes actually do much more than simply discouraging supplier opportunism, as AT's notion of outcome-based contracts emphasising positive incentives (e.g. bonus payments) appear to suggest. By setting positive 
expectations, they can indeed help to drive supplier proactivity and innovation and to improve relationships, provided that initial positive expectations are met.

On a more speculative level, relational contracts (MacNeil, 1980) appear to be underpinned by a promotion frame given that they set expectations for collaboration, flexibility and adaptation and relationship continuity (e.g. Lusch and Brown, 1996; Collins, 1999), although relational contracting studies sidestep the role of framing. Employing RFT and EVT can be useful for explicitly addressing the psychological impacts of relevant provisions of relational contracts on the counterparts' expectations and responses. Overall, RFT and EVT can be seen as useful complements to conventional contracting theories (TCE and AT) that enhance our understanding of contract design and its effects on buyer-supplier relationships.

Our study also informs RFT by stressing the effects of hybrid-framed contractual provisions and highlighting the role of several contingencies that determine the direction at which hybrid-framed contracts affect supplier expectations (see P1) and supplier responses (see P2). It seems worthwhile to further investigate additional conditions upon which each of the two frames (promotion and prevention) will be the dominant one, and how that relates to the overarching purpose of the contract, thereby shedding additional light on the subtle interplay between contract framing and exchange hazards (Weber, 2017).

The findings provide two key insights to managers of buying firms with respect to effective contract design. First, managers can differentiate their approach to contract framing based on the type of supplier relationship in focus: while prevention-framed contracts can be more effective in transactional supplier relations, promotion- and hybrid-framed contracts are conducive to the development of collaborative relations with strategic suppliers. Second, the design of effective promotion or hybrid-oriented contractual incentives requires attention to: a) setting up performance targets that strike a balance between aspiration and feasibility, and are also realistic in the medium and long run, b) introducing salient bonuses in connection with 
these targets, c) designing incentive structures that appropriately balance rewards (bonus) and risks (penalties), and d) explicating any uncontrollable factors influencing performance to consider them in the calculation of bonus /malus payments.

\subsection{Limitations and future research}

Our study has the following limitations. First, although we have demonstrated that the framing of incentives influences supplier responses, our research design does not fully allow for disentangling framing effects from firm-level influences on such supplier responses. An embedded case design (investigating multiple supplier contracts within multiple buying firms) could provide a more detailed picture, albeit it is arguably challenging to identify firms that intentionally differentiate the framing of their contracts. Second, limiting our study to a specific industry created the possibility of producing context-specific insights while controlling for cross-industry variations (Voss et al., 2002) in factors that would affect supplier responses (e.g. use of industry-specific contractual frameworks). However, a larger-scale study across industries is required to test our findings and to increase external validity.

The study presents several future research opportunities. The first involves more in-depth investigation of the relationship between the overarching purpose of the contract and contract framing, to find out what type of framing is most effective given a specific overall purpose. Specifically, an interesting question is whether the adoption of a promotion frame would result in even more effective transactional relationships as compared to employing a prevention frame. Another research avenue would be to relate contract framing to various contract functions (Schepker et al., 2014), studying in what way relevant provisions should be framed to support the intended contract function (Schilke and Lumineau, 2017). Future research could also explore the interaction between contract framing and suppliers' risk attitudes (Kim et al., 2007; Eisenhardt, 1989) in influencing behavioural and relational responses. Risk attitudes are 
connected to the dispositional tendency of parties to view situations either from a promotion or a prevention perspective (Weber and Mayer, 2011), and hence are likely to influence supplier responses to framing.

Our empirical study is nonetheless one of the few emphasising the role of contract framing and its impact on supplier behaviour. We are hopeful that our work will pave the way for further empirical research to develop a refined understanding of the effects of contract framing on buyer-supplier relationships. 


\section{References}

Barratt, M., Choi, T.Y. and Li, M. (2011), "Qualitative case studies in operations management: Trends, research outcomes, and future research implications", Journal of Operations Management, Vol. 29 pp. 329-342.

Bettencourt, B.A., Dill, K.E., Greathouse, S.A., Charlton, K. and Mulholland, A. (1997), "Evaluations of ingroup and outgroup members: The role of category-based expectancy violation", Journal of Experimental Social Psychology, Vol. 33 pp. 244-275.

Burgoon, J.K. (1993), "Interpersonal expectations, expectancy violations, and emotional communication", Journal of Language and Social Psychology, Vol. 12 pp. 30-48.

Caldwell, N.D. and Howard, M. (2014), "Contracting for complex performance in markets of few buyers and sellers", International Journal of Operations \& Production Management, Vol. 19 4, pp. 434-452.

Cao, Z. and Lumineau, F. (2015), "Revisiting the interplay between contractual and relational governance: A qualitative and meta-analytic investigation", Journal of Operations Management, Vol. 33-34 pp. 15-42.

Collins, H. (1999). Regulating Contracts. Oxford: Oxford University Press.

Datta, P.P. and Roy, R. (2011), "Operations Strategy for the Effective Delivery of Integrated Industrial ProductService Offerings Two Exploratory Defence Industry Case Studies", International Journal of Operations \& Production Management, Vol. 31 No. 5, pp. 579-603.

DeCanio, S.J. and Frech, H.E. III. (1993), "Vertical contracts: A natural experiment", Journal of Institutional and Theoretical Economics, Vol. 149 pp. 370-392.

Dubois, A. and Araujo, L. (2007), "Case research in purchasing and supply management: Opportunities and challenges", Journal of Purchasing and Supply Management, Vol. 13 No. 3, pp. 170-181.

Eisenhardt, K.M. (1989), "Agency theory: An assessment and review", The Academy of Management Review, Vol. 14 No. 1, pp. 57-74.

Eisenhardt, K.M. and Graebner, M.E. (2007), "Theory Building from Cases: Opportunities and Challenges", Academy of Management Journal, Vol. 50 No. 1, pp. 25-32.

Essig, M., Glas, A., Selviaridis, K. and Roehrich, J. (2016), "Performance-based contracting in business markets", Industrial Marketing Management, Vol. 59 No. 11, pp. 5-11.

Gibbert, M., Ruigrok, W. and Wicki, B. (2008), "What passes as a rigorous case study?", Strategic Management Journal, Vol. 29 No. 13, pp. 1465-1474.

Higgins, E.T. (1997), "Beyond pleasure and pain", American Psychologist, Vol. 52 pp. 1280-1300.

Higgins, E.T. (1998), "Promotion and prevention: Regulatory focus as a motivational principle", Advances in Experimental Social Psychology, Vol. 30 pp. 1-46.

Hubbard, R.G. and Weiner, R.J. (1986), "Regulation and long-term contracting in the U.S. natural gas markets", Journal of Industrial Economics, Vol. 35 No. 71-79.

Hypko, P., Tilebein, M. and Gleich, R. (2010), "Clarifying the concept of performance-based contracting in manufacturing industries", Journal of Service Management, Vol. 21 No. 5, pp. 625-655.

Jackson, L.A., Sullivan, L.A. and Hodge, C.N. (1993), "Stereotype effects on attributions, predictions and evaluations: No two social judgments are quite alike", Journal of Personality and Social Psychology, Vol. 65 pp. 69-84.

Jussim, L., Coleman, L.M. and Lerch, L. (1987), "The nature of stereotypes: A comparison and integration of three theories", Journal of Personality and Social Psychology, Vol. 52 pp. 536-546.

Kernaham, C., Bartholow, B.D. and Bettencourt, B.A. (2000), "Effects of category-based expectancy violation on affect-related evaluations: Toward a comprehensive model", Basic and Applied Social Psychology, Vol. 22 pp. 85-100.

Ketokivi, M.A. and Choi, T.Y. (2014), "Renaissance of case research as a scientific method", Journal of Operations Management, Vol. 32 pp. 232-240.

Kim, S.H., Cohen, M.A. and Netessine, S. (2007), "Performance contracting in after-sales service supply chains", Management Science, Vol. 53 No. 12, pp. 1843-1858.

Koning, P. and Heinrich, C.J. (2013), "Cream-Skimming, Parking and Other Intended and Unintended Effects of High-Powered, Performance-Based Contracts", Journal of Policy Analysis and Management Vol. 32 No. 3 , pp. 461-483.

Lumineau, F., Frechet, M. and Puthod, D. (2011), "An Organizational Learning Perspective on the Contracting Process", Strategic Organization, Vol. 9 No. 1, pp. 8-32.

Lusch, R., and Brown, J. (1996). "Interdependency, Contracting and Relational Behavior in Marketing Channels", Journal of Marketing , Vol. 60 No. 4, pp. 19-38.

Marshall, C. and Rossman, G.B. (1999), Designing Qualitative Research, Thousand Oaks, Sage.

Masten, S.E. and Crocker, K.J. (1985), "Efficient adaptation in long-term contracts: Take-or-pay provisions for natural gas", American Economic Review, Vol. 75 pp. 1083-1093.

Mayer, K.J. and Argyres, N.S. (2004), "Learning to contract: Evidence from the personal computer industry", Organization Science, Vol. 15 No. 4, pp. 394-410. 
MacNeil, I. (1980). The New Social Contract: An Inquiry into Modern Contractual Relations. New Haven: Yale University Press.

Miles, M.B. and Huberman, A.M. (1994), Qualitative data analysis, Thousand Oaks, Sage Publications.

Patton, M. (1990), Qualitative Evaluation and Research Methods, Newbury Park, CA, Sage.

Ragin, C.C. (1992). Casing and the Process of Social Enquiry. In: Ragin, C. C. \& Becker, H. S. (eds.) In What is a Case? Exploring the Foundations of Social Inquiry. Cambridge: Cambridge University Press.

Randall, W.S., Nowicki, D.R. and Hawkins, T.G. (2011), "Explaining the effectiveness of performance based logistics: A quantitative examination", International Journal of Logistics Management, Vol. 22 No. 3, pp. 324-338.

Roehrich, J. and Lewis, M. (2014), "Procuring complex performance: implications for exchange governance complexity", International Journal of Operations and Production Management, Vol. 34 No. 2, pp. 221-241.

Roney, C.J.R., Higgins, E.T. and Shah, J. (1995), "Goals and framin: ow outcome focus influences motivation and emotion", Personality \& Social Psychology Bulletin, Vol. 21 pp. 1151-1160.

Schepker, D.J., Oh, W.-Y., Martynov, A. and Poppo, L. (2014), "The many futures of contracts: Moving beyond structure and safeguarding to coordination and adaptation", Journal of Management, Vol. 40 No. January, pp. 193-225.

Schilke, O. and Lumineau, F. (2017), "The Double-Edged Effect of Contracts on Alliance Performance", Journal of Management, forthcoming. Available at SSRN: https://ssrn.com/abstract=2837554.

Selviaridis, K. and Norrman, A. (2015), "Performance-based contracting for advanced logistics services: challenges in its adoption, design and management", International Journal of Physical Distribution \& Logistics Management, Vol. 45 No. 6, pp. 592-617.

Selviaridis, K. and Spring, M. (2018), "Supply chain alignment as process: Contracting, learning and pay-forperformance", International Journal of Operations \& Production Management, Vol. 38 No. 3, pp. 732-755.

Selviaridis, K. and Wynstra, F. (2015), "Performance-based contracting: State of the art and future research directions", International Journal of Production Research, Vol. 53 No. 12, pp. 3505-3540.

Sols, A., Nowicki, D. and Verma, D. (2007), "Defining the Fundamental Framework of an Effective Performance-Based Logistics (PBL) Contract", Engineering Management Journal, Vol. 19 No. 2, pp. 40-50.

Strauss, A. and Corbin, J. (1990), Basics of qualitative research - grounded theory procedures and techniques, Newbury Park, Sage Publications.

Sumo, R., Van der Valk, W., Van Weele, A. J. and Bode, C. (2016), "Fostering incremental and radical innovation through performance-based contracting in buyer-supplier relationships", International Journal of Operations and Production Management, Vol. 36 No. 11, pp. 1482-1503.

Tykocinski, O., Higgins, E.T. and Chaiken, S. (1994), "Message framing, self-discrepancies, and yielding to persusive messages: The motivational significance of psychological situations", Personality \& Social Psychology Bulletin, Vol. 20 pp. 107-115.

Vanneste, B. and Puranam, P. (2010), "Repeated interactions and contractual detail: Identifying the learning effect", Organization Science, Vol. 21 No. 1, pp. 186-201.

Voss, C., Tsikriktsis, N. and Frohlich, M. (2002), "Case research in operations management", International Journal of Operations and Production Management, Vol. 22 No. 2, pp. 195-219.

Wacker, J.G., Yang, C. and Sheu, C. (2016), "A transaction cost economics model for estimating performance effectiveness of relational and contractual governance: Theory and statistical results", International Journal of Operations \& Production Management, Vol. 36 No. 11, pp. 1551-1575.

Weber, L. (2017), "A Sociocognitive View of Repeated Interfirm Exchanges: How the Coevolution of Trust and Learning Impacts Subsequent Contracts", Organization Science, Vol. 28 No. 4, pp. 744-759.

Weber, L. and Mayer, K.J. (2011), "Designing effective contracts: Exploring the influence of framing and expectations", Academy of Management Review, Vol. 36 No. 1, pp. 53-75.

Weber, L., Mayer, K.J. and Macher, J.T. (2011), "An analysis of extendibility and early termination provisions: The importance of framing duration safeguards", Academy of Management Journal,, Vol. 54 pp. 182-202.

Williamson, O.E. (1985), The economic institutions of capitalism, New York, The Free Press.

Williamson, O.E. 2000. Empirical microeconomics: Another perspective. Berkeley: University of California. Yin, R.K. (2009), Case study research: design and methods, Thousand Oaks, California, Sage Publications Inc. 


\section{Appendix A: List of interviewed managers across the cases}

\begin{tabular}{ll}
\hline Case study & Interviewee role and function \\
\hline Case A & Supplier \\
1. Managing Director \\
2. Operations Director \\
3. BD Manager, Business Control and Development \\
4. BD Manager, Business Control and Development \\
5. Business Developer, Business Control \& Development \\
6. BD Manager, Business Control and Development \\
7. Business Developer, Business Control \& Development \\
8. Business Developer, Business Control \& Development \\
9. BD Manager, Business Control and Development \\
10. BD Manager, Business Control and Development \\
11. Logistics Network Manager, Distribution Network \\
12. BD Manager and Logistics Network Manager \\
13. BD Manager and Business Developer \\
14. Logistics Network Manager, Distribution Network \\
15. Operations Director
\end{tabular}

Case B Supplier

1. Vice President, Global BD

2. BD General Manager, Inbound transport

3. BD General Manager, Outbound transport

4. BD General Manager, Packaging

5. Key Account Manager 1, BD

6. Key Account Manager 2, BD

7. Key Account Manager 3, BD

8. Internal Control Manager, BD

9. Operations Manager, Distribution Planning \& Control

10. Operations Manager \& Traffic Coordinator, Operations

11. Legal Counsel, Legal

12. Insurance Purchaser; Damage Prevention \& Claims Handling Manager, Risk Management Division

13. Financial \& Control Manager, Finance

14. Vice President, Purchasing

15. Internal Control Manager, BD

Case C Supplier

1. Global Key Account Manager, BD

2. Global Key Account Manager, BD

3. Manager Air and Outsourcing, Global Accounts

4. Manager Air and Outsourcing, Global Accounts

5. Ocean Freight and Air Manager, Operations

Buyer

6. Global Supply Manager and Outbound Logistics Manager

7. Global Supply Manager and Outbound Logistics manager

8. Outbound Logistics Manager 


\section{Appendix B: The interview guide}

\section{BACKGROUND INFORMATION}

- Organization information (industry, core business, products/services, annual turnover and market share, key customers/suppliers)

- What is your position/role in relation to the company's organizational structure?

- What does your job entail?

\section{THE SUPPLY CHAIN AND SERVICE SCOPE}

- What is the structure/mapping of the customer's supply chain?

- What is the key material and information flows in the customer's supply chain?

- What is the scope of the provided logistics service(s)?

- Can you briefly describe the services provided within the customer's supply chain?

- What is the role and input of key parties (LSP, customer, any sub-contractors) in service performance achievement?

\section{MANAGING RELATIONSHIPS}

- Can you briefly provide an overview of the customer/LSP relationship in focus?

- Can you provide a brief account of the customer/LSP relationship history and evolution over time (if applicable)?

- What are the main challenges you face regarding the management of the customer/LSP relationship? (e.g. critical events)

- What is the role of the formal contract vis-à-vis collaboration and trust in managing the LSP-customer relationship?

\section{CONTRACT DESIGN (PERFORMANCE, INCENTIVES, RISK)}

- What do you perceive as key challenges in terms of designing a performance-based contract?

- How is the service specified in the contract (service specifications)?

- How is 'customer value' defined and measured, if at all?

- How is performance defined in the LSP-customer contract in terms of KPIs and service level targets?

- $\quad$ Are there any extra-contractual performance measures (e.g. operational KPIs)?

- What is the design of the payment mechanism included in the customer/LSP contract and why?

- What types of performance incentives are included? Bonus or penalties? Or both?

- What is the organization's attitude towards performance-related risks? What factors influence this attitude?

- Are you prepared to accept an increased amount of risk in this specific customer/LSP contract? Under what conditions?

\section{CONTRACT MANAGEMENT}

- What do you perceive as key challenges in managing this contract? Any examples?

- How are service performance and KPIs measured and managed?

- What kinds of performance measurement and management systems are being used?

- How is service performance reported?

- How is financial risk allocated and managed in this contract?

- To what extent are the designed performance incentives effective? In what sense?

- What is their impact on the customer-LSP relationship?

- Are there any unintended consequences of the designed performance incentives?

- Are your expectations from this contract met? Why/why not?

\section{CLOSING QUESTIONS}

- Can you suggest any relevant documents to look at?

- Access to contract /SLA?

- Can you suggest other interviewees to talk to?

- Can you suggest further research/relevant aspects? 


\section{Tables}

Table 1. Definitions of key constructs and theory-informed expectations and behavioural and relational responses under different contract frame types (based on Weber and Mayer, 2011)

\begin{tabular}{|c|c|c|c|}
\hline & Definitions & Prevention frame & Promotion frame \\
\hline $\begin{array}{l}\text { Performance } \\
\text { incentives }\end{array}$ & $\begin{array}{l}\text { The motivation offered in the } \\
\text { contract to achieve certain } \\
\text { targeted or desired performance. }\end{array}$ & $\begin{array}{l}\text { Penalties; performance targets as } \\
\text { minimum that must be achieved }\end{array}$ & $\begin{array}{l}\text { Bonus/ gain-sharing } \\
\text { mechanisms; performance } \\
\text { targets as maximum that may } \\
\text { be achieved }\end{array}$ \\
\hline $\begin{array}{l}\text { Expectations } \\
\text { regarding the } \\
\text { exchange and } \\
\text { the relationship }\end{array}$ & $\begin{array}{l}\text { The hopes/anticipations regarding } \\
\text { the exchange/ the relationship and } \\
\text { the atmosphere within which this } \\
\text { will take place. Both are shaped } \\
\text { by perceptions triggered by the } \\
\text { contract frame. }\end{array}$ & $\begin{array}{l}\text { Overall negative; expectations for } \\
\text { impersonal, business-like } \\
\text { behaviours, and impersonal, } \\
\text { detached, transactional relationships }\end{array}$ & $\begin{array}{l}\text { Overall positive; expectations } \\
\text { for behaviours that go beyond } \\
\text { the letter of the contract, and } \\
\text { close, nurturing, collaborative } \\
\text { relationships }\end{array}$ \\
\hline $\begin{array}{l}\text { Supplier } \\
\text { behavioural } \\
\text { responses }\end{array}$ & $\begin{array}{l}\text { The behaviours the supplier } \\
\text { displays during the exchange. }\end{array}$ & Vigilance & $\begin{array}{l}\text { Creativity, flexibility, } \\
\text { cooperation }\end{array}$ \\
\hline $\begin{array}{l}\text { Supplier } \\
\text { relational } \\
\text { responses }\end{array}$ & $\begin{array}{l}\text { The behaviours the supplier } \\
\text { displays in the overall } \\
\text { relationship. }\end{array}$ & Arm's length, impersonal & Close, personal, trusting \\
\hline $\begin{array}{l}\text { Meeting/ } \\
\text { violating } \\
\text { expectations }\end{array}$ & $\begin{array}{l}\text { The ex-ante hopes/anticipations } \\
\text { being confirmed/ disconfirmed } \\
\text { during contract execution. }\end{array}$ & $\begin{array}{l}\text { Confirmation: reinforces the } \\
\text { business-like, transactional } \\
\text { character of the exchange; } \\
\text { Disconfirmation: triggers high } \\
\text { partner satisfaction and closer } \\
\text { relationships }\end{array}$ & $\begin{array}{l}\text { Confirmation: } \\
\text { reinforces positive, close and } \\
\text { cooperative relationships; } \\
\text { Disconfirmation: undermines } \\
\text { the relationship, leads to } \\
\text { partner dissatisfaction and } \\
\text { possibly termination }\end{array}$ \\
\hline
\end{tabular}


Table 2. Overview of the case studies

\begin{tabular}{|c|c|c|c|}
\hline & Case A & Case B & Case C \\
\hline Supplier & $\begin{array}{l}\text { Supplier A: Fourth-party } \\
\text { logistics provider specialising } \\
\text { in the food retail market with } \\
\text { expertise also in pharma and } \\
\text { healthcare }\end{array}$ & $\begin{array}{l}\text { Supplier B: Logistics provider } \\
\text { specialising mainly in the } \\
\text { automotive industry with } \\
\text { expertise also in aerospace and } \\
\text { industrial sectors }\end{array}$ & $\begin{array}{l}\text { Supplier C: Logistics provider specialising } \\
\text { in freight forwarding and air and ocean } \\
\text { freight transport (expertise in FMCG, } \\
\text { fashion and retail). }\end{array}$ \\
\hline No of employees & 80 & 1,200 & 30,000 \\
\hline Turnover & $€ 90$ million & $€ 1,069$ million & $€ 6,800$ million \\
\hline Buyer & $\begin{array}{l}\text { Buyer A: International food } \\
\text { retailer operating also a chain } \\
\text { of in-store restaurants. }\end{array}$ & $\begin{array}{l}\text { Buyer B: Manufacturer of } \\
\text { automobiles and automotive } \\
\text { engines }\end{array}$ & $\begin{array}{l}\text { Buyer C: Manufacturer of packaging } \\
\text { solutions and industrial packaging } \\
\text { production machines }\end{array}$ \\
\hline No of employees & 30,000 & 21,500 & 23,540 \\
\hline Turnover & $€ 1,400$ million & $€ 13,200$ million & $€ 11,075$ million \\
\hline $\begin{array}{l}\text { Services } \\
\text { provided to } \\
\text { buyer }\end{array}$ & $\begin{array}{l}\text { Supply \& demand } \\
\text { management, product } \\
\text { purchasing, ERP solution, } \\
\text { business development \& } \\
\text { consulting, finance, logistics } \\
\text { network management, } \\
\text { inventory ownership \& } \\
\text { management }\end{array}$ & $\begin{array}{l}\text { Inbound \& outbound } \\
\text { transportation management, } \\
\text { returnable packaging services, } \\
\text { freight insurance services, quality } \\
\text { control \& maintenance services, } \\
\text { and logistics consulting. }\end{array}$ & $\begin{array}{l}\text { Freight forwarding, shipment booking \& } \\
\text { coordination, customs clearance, invoice } \\
\text { administration and cost control, carrier } \\
\text { tendering \& performance monitoring. }\end{array}$ \\
\hline $\begin{array}{l}\text { Key } \\
\text { performance } \\
\text { indicators }\end{array}$ & $\begin{array}{l}\text { Transport delivery on time \% } \\
\text { Picking accuracy \% } \\
\text { Product damages \% } \\
\text { 'Perfect orders' (OTIF) \% } \\
\text { Product availability \% (at } \\
\text { stores and central warehouse) } \\
\text { Supply chain cost reduction } \\
\% \text { (as compared to cost } \\
\text { baseline from previous year) }\end{array}$ & $\begin{array}{l}\text { Packaging availability } \% ; \\
\text { Packaging delivery precision \%; } \\
\text { Transport delivery precision } \% ; \\
\text { No. of product damages/loss } \\
\text { Annual logistics cost savings } \% \text { in } \\
\text { terms of efficient transport and } \\
\text { returnable packaging solutions (as } \\
\text { compared to cost baseline in } \\
\text { previous year) }\end{array}$ & $\begin{array}{l}\text { Total freight cost reduction \% } \\
\text { Ocean freight cost reduction } \% \\
\text { Air freight cost reduction \% } \\
\text { Deliveries Accuracy \% } \\
\text { Accuracy of sailing list when using multiple } \\
\text { carriers \% } \\
\text { CO2 emissions reduction \% } \\
\text { End customer satisfaction score > threshold } \\
\text { Logistics cost reduction \% (resulting from } \\
\text { Supplier C innovations) }\end{array}$ \\
\hline \multirow[t]{2}{*}{$\begin{array}{l}\text { Payment } \\
\text { mechanism and } \\
\text { performance } \\
\text { incentives }\end{array}$} & $\begin{array}{l}\text { 'Fixed-price-plus-incentive- } \\
\text { fee' mechanism. Incentive fee } \\
\text { (bonus) is linked to " } 95 \% \\
\text { product availability" and } \\
\text { "supply chain cost reduction" } \\
\text { (annual target) }\end{array}$ & $\begin{array}{l}\text { 'Cost-plus-management-fee' } \\
\text { mechanism for transport } \\
\text { management services. } \\
\text { Unit-price mechanism for } \\
\text { packaging services (per package } \\
\text { unit). }\end{array}$ & $\begin{array}{l}\text { 'Unit-price-plus-incentive-fee' mechanism. } \\
\text { Bonus /malus payment calcuated based on } \\
\text { overall score (weighted KPIs): } \\
\text { Score 5: }+3 \% \\
\text { Score 4: }+1.5 \% \\
\text { Score 3: } 0.0 \% \text {; } \\
\text { Score 2: }-0.5 \%\end{array}$ \\
\hline & $\begin{array}{l}\text { Bonus payment only if }>90 \% \\
\text { of supply chain cost saving } \\
\text { target achieved. Bonus } \\
\text { increases substantially only if } \\
\text { Supplier A achieves }>99 \% \text { of } \\
\text { cost saving target. No bonus } \\
\text { payment for cost savings if } \\
\text { product availability is below } \\
\text { the } 83 \% \text { threshold. }\end{array}$ & $\begin{array}{l}\text { Standard penalties for 'non- } \\
\text { performance' in relation to } \\
\text { delivery delays, product damages } \\
\text { and any direct losses for Buyer B } \\
\text { e.g. } 1 \text { Basic Amount unit (as } \\
\text { defined in local currency) per } \\
\text { instance or } 10 \text { units per year. } \\
\text { No bonus for performance } \\
\text { achievement or improvement }\end{array}$ & $\begin{array}{l}\text { Score 1: }-1.0 \% \\
\text { Gain-share model for 'logistics cost } \\
\text { reduction \%'. Cost savings-sharing } \\
\text { mechanism introduced: } \\
<5 \% \text { saving= } 10 \% \text { share for [Supplier C] } \\
5-20 \% \text { saving }=25 \% \text { share for[Supplier C] } \\
>20 \% \text { saving= } 50 \% \text { share for[Supplier C] }\end{array}$ \\
\hline $\begin{array}{l}\text { Length of } \\
\text { exchange } \\
\text { relationship }\end{array}$ & 19 years & 30 years (terminated in 2014) & 13 years \\
\hline $\begin{array}{l}\text { Length of period } \\
\text { covered by study }\end{array}$ & 3 years $(2011-2014)$ & 3 years $(2011-2014)$ & 2 years $(2012-2014)$ \\
\hline $\begin{array}{l}\text { Payment } \\
\text { mechanism in } \\
\text { force prior to } \\
\text { study period }\end{array}$ & $\begin{array}{l}\text { 'Cost-plus-management-fee'. } \\
\text { No performance incentives, } \\
\text { but joint intent to introduce } \\
\text { gain-share to reflect Buyer } \\
\text { A's changing emphasis } \\
\text { towards cost reduction }\end{array}$ & $\begin{array}{l}\text { Same payment mechanisms as } \\
\text { above, no changes. }\end{array}$ & $\begin{array}{l}\text { 'Unit-price' mechanism, no performance } \\
\text { incentives included. The bonus /malus } \\
\text { provision and the gain-share for logistics } \\
\text { cost reducion were first agreed in } 2012 \text {. }\end{array}$ \\
\hline
\end{tabular}


Table 3. Criteria employed to evaluate the quality of case studies

\begin{tabular}{|c|c|}
\hline Evaluation criteria & Measures taken to meet criteria \\
\hline Internal validity & $\begin{array}{l}\text { - Drawing on different literatures (contracting and contract framing) and } \\
\text { theoretical perspectives (RFT and EVT) to discuss cross-case findings } \\
\text { - Using tables to facilitate within- and cross-case analyses of framing } \\
\text { performance incentives and their effectiveness (Tables } 2 \text { and 4). }\end{array}$ \\
\hline Construct validity & $\begin{array}{l}\text { - Access to formal contracts enabled analysing the content of performance } \\
\text { incentives, which provided clear indications of how they were framed. } \\
\text { Conducting interviews with supplier managers from various functions to } \\
\text { triangulate their views of the designed performance incentives and their } \\
\text { effectiveness. } \\
\text { Triangulating interviewee accounts with documents (e.g. SLAs and contract } \\
\text { payment mechanisms) in order to address retrospective rationalisation issues } \\
\text { and elicit more detailed data on the framing of performance incentives. }\end{array}$ \\
\hline External validity & $\begin{array}{l}\text { - Collecting rich data from multiple sources: interviews and formal contracts } \\
\text { Writing up detailed within-case descriptions and analyses so that readers } \\
\text { could potentially transfer findings to other contexts. } \\
\text { Relating findings back to the key theoretical perspectives employed (RFT } \\
\text { and EVT) and existing literature on contract framing to enable analytical } \\
\text { generalisation and theory elaboration. }\end{array}$ \\
\hline Reliability & $\begin{array}{l}\text { Developing a database of the interviewed managers (see Appendix A). } \\
\text { - Developing and using an interview guide across all cases (see Appendix B). } \\
\text { - } \quad \text { Developing and updating a database with all interview transcripts, field } \\
\text { notes, analysis memos and coding schemes. } \\
\text { - Documenting the data coding and analysis procedure. }\end{array}$ \\
\hline
\end{tabular}


Table 4. The effects of framing performance incentives in the studied contracts

\begin{tabular}{|c|c|c|c|}
\hline & Case A & Case B & Case C \\
\hline $\begin{array}{l}\text { Framing of } \\
\text { performance } \\
\text { incentives }\end{array}$ & $\begin{array}{l}\text { Promotion frame: bonus for } \\
\text { hitting product availability and } \\
\text { supply chain cost reduction } \\
\text { targets. Resulted from } \\
\text { negotiations regarding which } \\
\text { performance aspect to link } \\
\text { incentive fee to, and whether to }\end{array}$ & $\begin{array}{l}\text { Prevention frame: penalty } \\
\text { clause for non-performance of } \\
\text { services in terms of delays in } \\
\text { product deliveries and loss or } \\
\text { damage of products. }\end{array}$ & $\begin{array}{l}\text { 'Hybrid' frame with promotion } \\
\text { and prevention elements: penalty } \\
\text { and bonus clause for service } \\
\text { performance; gain-share } \\
\text { mechanism for savings arising } \\
\text { from service innovation. }\end{array}$ \\
\hline
\end{tabular}

also include a penalty element

(eventually rejected).

\section{Ex-ante expectations regarding the exchange and relationship}

\section{Behavioural responses}

\section{Relational responses}

\section{Meeting \\ /violating expectations}

The gain-share scheme set positive expectations: for alignment with buyer's interests, and for buyer-supplier cooperation.

Joint aspirational goal to improve supply chain efficiency and to spur further business growth seen as important by Buyer A, who perceived Supplier A as its strategic partner. Supplier A's excitement to grow further alongside Buyer A.

Supplier A's emphasis on achieving the supply chain cost reduction target in line with buyer's interests. Cooperation and flexibility to achieve goals were emphasised by Supplier A.

Joint effort to achieve cost reduction targets. Supplier A stressed trust and the importance of Buyer A's cooperation and active involvement in implementing required supply chain changes.

Supplier A's positive ex ante expectations were overall met. However, the contract did not specify how the cost reduction targets would evolve over time. Supplier A concerns regarding intensity of cost reduction targets and the salience of bonus payment led to emphasis on securing a viable 'fixed fee' element regardless of incentive fee design.
The prevention-framed incentives set negative expectations: for an adversarial working atmosphere, and for Buyer B's close monitoring of Supplier B's behaviour and of service costing /pricing (transparency required). Despite Supplier B's generic reluctance to accept penalty-based incentives in contractual relations with its customers, they had to accede to Buyer B's request (bargaining power). Buyer B transactional view of Supplier B relationship which led to emphasis on supplier opportunism mitigation and close control of cost and prices.

Supplier B lacked motivation to improve services given lack of related rewards. Supplier B vigilance and focus on mitigating financial risks in relation to the penalty payments.

Supplier B frustration regarding buyer's focus on close monitoring and cost control. Arm's length relationship given Buyer B's focus on close monitoring of Supplier B's behaviour and a safeguarding atmosphere.

Supplier B's expectations for an adversarial atmosphere were met and led to a deteriorating relationship. Contract eventually terminated. Supplier B contrasted relationship with Buyer B against another customer relationship whereby a gainshare scheme instigated collaboration.
The 'hybrid' frame of incentives set Supplier C positive expectations for close collaboration with Buyer $\mathrm{C}$ to proactively improve performance and introduce service innovations.

Buyer C emphasised the creation of such an aspirational goal of proactive improvement and innovation, as Supplier C was seen as a strategic partner. This aspiration goal was complemented by 'must-be-met' goals e.g. freight cost reduction.

Supplier C change of mentality towards proactive performance improvement and creativity for service innovation. Alignment of Supplier' Cs incentives with those of Buyer C.

Collaboration and improved buyer-supplier relationship overall, despite temporary harm to relationship in relation to incident of the penalty payment imposed to Suppler C.

In the main, Supplier C's positive expectations were met; but they were also violated in specific instances: (a) Buyer C's responsibilities to achieve the improvements, (b) attribution of Supplier C's innovative ideas, and (c) request to pay penalty for under-performance.

Relevant contractual provisions were revised and refined to reinstate collaboration and fairness (as perceived by Supplier C). 